\title{
URGENSI NILAI AGAMA PADA MORAL ANAK DI ERA SOCIETY 5.0
}

\author{
Lilis Madyawati ${ }^{1}$, Marhumah $^{2}$, Ahmad Rafiq $^{3}$ \\ ${ }^{1}$ Universitas Muhammadiyah Magelang, Jl. Tidar no.21 Magelang, Indonesia \\ ${ }^{2,3}$ Universitas Islam Negeri Sunan Kalijaga Yogyakarta, Indonesia \\ e-mail: lilis_madya@yahoo.co.id
}

\begin{abstract}
This study aims to identify and describe the importance of religious and moral values instilled by parents in welcoming society in the 5.0 era. This research is qualitative with library research. A sorting method with two determining elements, children's spiritual and moral values, was used to analyze the data. Researchers explain the data into categories and characteristics. We also limited the data, performed content analysis, and studied the text literature. In the era of society 5.0:1) parents are advised to educate their children as did Rasulullah (SAW);2) parents are responsible for children's academic education; 3) parents are encouraged to grow the Rabbani generation (religion-based); 4) parents need to bring up good habits. Due to increasingly sophisticated technological developments, parents must increase their knowledge of this new technology, positively direct digital devices and media, and balance the time in using digital media and real-life interactions. In addition, parents are also encouraged to choose programs or applications that are positive for children that can positively impact their child's growth and development.
\end{abstract}

Keywords: Religious and Moral Values, Children, 5.0 Society Era

\begin{abstract}
ABSTRAK
Tujuan penelitian ini untuk mengetahui serta menggambarkan pentingnya pendidikan moral dan agama pada anak yang disiapkan orang tua dalam menghadapi masyarakat keterbaharukan era society 5.0. Penelitian ini berjenis penelitian kualitatif dengan menggunakan library research, Kemudian data dianalisis menggunakan metode pilah dengan unsur penentu pendidikan moral agama anak. Peneliti menjabarkan data ke dalam kategori dan karakteristiknya. Peneliti juga melakukan pembatasan data, content analysis, serta melakukan analisis teks literatur. Dalam masyarakat keterbaharukan era society 5.0 ini: 1) perlu dan dihimbau orang tua yang dapat mendidik anaknya seperti Rasulullah saw.; 2) Orang tua yang memiliki tanggung jawab pendidikan intelektual bagi anak- anaknya; 3) Membangun Generasi Robbani; 4) Kebiasaan yang dibangun orang tua. Dalam kaitannya dengan teknologi canggih, ada baiknya orang tua juga harus menambah pengetahuan mengenai penggunaan teknologi, mengarahkan pemanfaatan media dan perangkat digital secara jelas, atau mengatur waktu memakai perangkat digital melalui interaksi dunia nyata. Dapat pula orang tua memilihkan program/ aplikasi positif yang dapat memberikan dampak baik pada tumbuh kembang anak.
\end{abstract}

Kata Kunci: Agama Moral, Anak, Masyarakat Keterbaharuan

\begin{tabular}{|c|c|c|c|}
\hline FIRST RECEIVED: & REVISED: & ACCEPTED: & PUBLISHED: \\
25 April 2021 & 20 October 2021 & 24 October 2021 & 31 October 2021 \\
\hline
\end{tabular}

\section{PENDAHULUAN}

Masyarakat keterbaharukan yang biasa disebut masyarakat era 5.0 yaitu sebuah konsep diadopsi oleh Jepang. Hal ini sebagai antisipasi terhadap globalisasi akibat munculnya revolusi industri 4.0. Hal ini merupakan hal yang wajar terjadi, merupakan dampak dari industri 4.0 yang juga sudah banyak menghasilkan perubahan dalam segala hal dan masyarakat umumnya. Masyarakat keterbaharukan 5.0 ini mencoba menjawab adanya dampak dan tantangan dari adanya era industri 4.0. Efek dari era industri 4.0 dengan adanya disrupsi, dunia menjadi bergejolak, adanya ketidakpastian, ambiguitas, serta

Lilis Madyawati, Marhumah, Ahmad Rafiq Urgensi Nilai Agama Moral Anak pada Era Society 5.0 
kompleksitas. Sejalan dengan yang diungkapkan oleh Hanafiah dan Soomro, (2021), bahwa masyarakat era 5.0 mencoba mencari solusi dan kebaharuan dari era industri 4.0. Selain ada sisi kemudahan yang merupakan efek dari era society 5.0, manusia akan semakin malas dalam mengerjakan sesuatu, manusia berkecenderungan mengandalkan pekerjaannya pada teknologi canggih yang tersedia di era itu.

Masyarakat keterbaharukan yaitu sekelompok manusia yang dapat menyelesaikan berbagai masalah dengan cara menggunakan inovasi akibat adanya revolusi industri 4.0 di antaranya internet, kecerdasan buatan (kecerdasan artificial), Big Data, juga perangkat lain guna kualitas hidup manusia yang lebih baik. Hal ini tampak dalam 'Kebijakan Dasar Ekonomi manajemen dan segala perubahannya pada tahun 2016 (Economic Activity and Price). Pada masyarakat ini terdapat kelompok/ komunitas manusia yang mengatur tatanan bidang ekonomi dan kaitannya dengan sosial. Hal ini dilakukan dengan dunia maya dan ruang fisik.

Konsep ini akan membantu masyarakat sehingga kehidupan lebih baik. Hal ini akan berdampak pada semua aspek kehidupan. Selain itu tren pendidikan di Indonesia berupa online learning telah berakibat pada menjamurnya peluang bisnis di bidang pendidikan dengan bimbingan belajar berbasis online. Sistem penerimaan peserta didik baru maupun sistem ujian telah berubah dari yang semula paper-based test menjadi online based test. (Bennett; Braak, J.; Heller, R.S).

\section{World Economic Forum (WEF)} menyampaikan bahwa manfaatnya komunitas yang dipengaruhi oleh data- data yang luar biasa dan data- data yang terkelola guna lajunya pertumbuhan di masa yang akan datang. Melalui masyarakat keterbaharukan data- data akan menggerakkan dan menghubungkan segala sesuatu menjembatani adanya ketidakselarasan antara kaya dan miskin. Tariq, Tania, dan Gutreen 2021) dalam Pakistan Journal Commence and Social Sciences berpendapat bahwa masyarakat keterbaharukan ini akan merupakan komunitas yang mengaplikasikan teknologi yang berpusat pada kehidupan manusia yang berpijak pada kebiasaan era industri 4.0. Menjadi sangat penting guna memberdayakan manusia dengan memasukkan beragam kepentingan dan teknologi digitalisasi.

Guna menghadapi tantangan ini sangatlah perlu menyiapkan anak- anak sejak dini anak- anak yang berkualitas berkeseimbangan. Pendidik dalam melaksanakan pendidikan baik lingkungan formal maupun nonformal haruslah sesuai dengan konsep pendidikan Islam. Pendidikan yang islami hendaknya menghasilkan anak didik yang kelak seimbang antara aspek agama dengan aspek keberadaban (budaya, nilai, dan teknologi). Sangat dibutuhkan nilai- nilai rahmatan lilálamin. Sejalan dengan surat AlAnbiya ayat 107 "Allah mengutus Muhammad guna menjadi rahmat untuk seisi alam". Bila pendidikan agama melalui penanaman nilai agama moral pada anak diabaikan, dapat berakibat pada tumbuh kembang anak dan lebih berdampak pada terbentuknya kepribadian yang tidak sehat utamanya dalam perkembangan mencapai kedewasaan. Situasi dan kondisi rumah/ keluarga yang tidak ramah, faktor ekonomi yang dapat mengeksploitasi anak, keluarga broken home menjadi pemicu kurangnya para orang tua menanamkan pendidikan moral dan agama sejak dini.

Dari hasil observasi, terdapat gejalagejala negatif yang dilakukan anak, misalnya bertengkar dengan teman, berkata kasar dan kotor, mem-bully-teman, menghindar dari

Lilis Madyawati, Marhumah, Ahmad Rafiq Urgensi Nilai Agama Moral Anak pada Era Society 5.0 
tanggung jawab rumah dan sekolah, gelisah, suka berbohong, dan menyakiti hati teman. Kondisi ini sangat dimungkinkan dipicu oleh kondisi memasuki era keterbaharuan yang juga didukung dengan: pola asuh orang tua, orang tua yang tidak hangat, lingkungan yang egosentris, persetemanan sebaya yang kurang kondusif, maupun kondisi sosial ekonomi orang tua. Selain faktor tersebut dekadensi ini terjadi karena perkembangan ilmu pengetahuan teknologi menggoreskan persoalan negatif. Terkjadinya sikap konsumeristis, hedonistis, dan sekuleristis merupakan embrio terjadinya dekadensi ini. Oleh sebab itu, betapa pentingnya pendidikan moral dan agama anak usia dini. Para orang tua dan guru turut aktif serta bertanggung jawab ketika memberikan pendidikan yang utama, berkewajiban membantu, merawat, mengarahkan anak- anak kelak menjadi pribadi muslim yang unggul. Penelitian ini bertujuan mengetahui serta mendeskripsikan pentingnya nilai moral agama anak yang disiapkan orang tua dalam memasuki masyarakat keterbaharuan.

Pada hakekatnya masyarakat keterbaharukan era 5.0 adalah masa dalam kehidupan bermasyarakat yang telah terpadu bersama sistem teknologi berupa IoT dan Artificial Intelligence yang bisa mengolah big data dan menganalisisnya. Gagasan masyarakat keterbaharukan era 5.0 didukung oleh adanya pertimbangan aspek humaniora sehingga didapatkan aspek keseimbangan dalam mengimplementasikan aspek tersebut (Sarif, 2017). Prasetyo (2018) mengungkapkan bahwa masyarakat keterbaharukan society 5.0 memanfaatkan sistem kecerdasan buatan (Artificial Intelligence) guna menyejahterakan kehidupan. Penggunaan dan pemanfaatan teknologi di era ini berprinsip pada inklusi, berfokus pada manusia, berkesinambungan, dan inovatif. Wujud masyarakat ini selanjutnya menjadi paradigma menarik bagi manusia yang menjalani kehidupan di era ini.

Era society 5.0 mewujudkan Smart City yaitu Kota Pintar berupa suatu tawaran pengembangan kota yang mengaplikasikan teknologi dengan kreatif, efektif, inovatif, dan efisien melalui infrastruktur fisik, ekonomi, dan sosial di sebuah wilayah sehingga memperbaiki dan meningkatkan kualitas hidup yang lebih baik (Qasem; AlMobaideen, W, 2019). Kota di zaman masyarakat keterbaharukan ini merupakan kota yang telah memadupadankan teknologi informasi dan komunikasi dalam pengelolaan sehari- hari bertujuan memperbaiki kenyamanan serta kesejahteraan warganya. Dengan mudahnya masyarakat dalam hal mengakses informasi, bertambahnya pengetahuan dan wawasan untuk mendidik masyarakat menjadi lebih pintar. Hadist Rasulullah menjelaskan makna menjadi lebih baik dalam H.R Al- Hikam Artinya: 'Seseorang yang lebih baik dari sebelumnya, tergolong orang beruntung. Bila dia mengalami kemunduran, dia termasuk merugi'.

Pada masyarakat keterbaharukan era 5.0 dibutuhkan, ditawarkan, dan dilatih cara berpikir sesuai dengan kondisi zaman, berupa berpikir analisis, kreatif, serta kritis. Hal ini yang dinamakan cara berpikir Higher Order Thinking Skills (HOTS), cara berpikir yang kompleks, berjenjang, dan sistematis. Berikut ini sebuah hadits tentang berpikir kritis dari H.R At-Tirmidzi "Órang yang mampu mengendalikan diri dan beramal, dialah orang yang cerdas. Dia akan berpikir untuk kehidupan setelah mati. Orang lemah yaitu orang yang hanya mengikuti hawa nafsu. Dia berharap kepada Allah dengan harapan kosong, harapan yang sia- sia”.

Lilis Madyawati, Marhumah, Ahmad Rafiq Urgensi Nilai Agama Moral Anak pada Era Society 5.0 
Kemampuan dan perkembangan moral dan agama pada anak yaitu kemampuan anak dalam hal bersikap dan bertingkah laku. Islam banyak mengajarkan nilai positif yang bermanfaat dalam kehidupan bermasyarakat seorang anak kelak. Oleh karena itu sangatlah diperlukan penanaman dan pengembangan pendidikan moral dan agama. Islam banyak membahas penanaman pendidikan moral dan agama yang dapat diaplikasikan secara tepat. (Ananda, R; 2017). Islam mengakui banyak metode- metode penting yang telah diberikan kepada anak saat menanamkan dan memahamkan pendidikan moral dan agama. Cara yang dimaksud melalui: bermain, bercerita, outbond, bermain peran, karya wisata, diskusi, pembiasaan, dan keteladanan.

Perihal mendidik anak serta menanamkan nilai agama dan moral padanya telah banyak dilakukan tokoh-tokoh muslim terdahulu, misalnya Nabi dan LukmanulHakim. Lukman berpesan bahwa menyayangi dan mendidik anak hendaknya dilakukan sesuai tingkatan usia dan development tasknya. Nabi dan Al-Qur'an pun telah merumuskan pendidikan anak sesuai Islam, yaitu: a) memperdengarkan Al-Qur'an sejak lahir. Memperdengarkan bacaan Al-Qur'an ini dilakukan semenjak anak dalam kandungan sampai anak lahir. Setelah bayi lahir secara teratur memperdengarkan bacaan Al-Qur'an setiap hari; b) mengejarkan dasar- dasar Islam. H.R Ibnu Abbas mengungkapkan bahwa langkah awal mengenalkan anak pada kebesaran Allah. Pada umur 3 tahun mengajari anak dengan 'lailaha illallah', mengajarkan kalimat Muhammadar Rasulullah; c) memberi contoh dan mengajarkan salat. Hal ini tertera dalam H.R Ahmad dan Abu Dawud untuk menyuruh anak salat berumur tujuh tahun; d) mengajarkan tauhid; e) mengajarkan puasa, dilakukan dengan cara mengenalkan dan mengajarkan kepada anak berkah dan manfaat dari berpuasa; f) memberi nama anak dan nama panggilan yang baik. 'Hormatilah anakanakmu dan memperhatikan pendidikannya'. Karena anak merupakan karunia dari Allah (H.R Ibnu Majah).

Ahmad, A; Amalia, D (2018) dalam artikelnya mengungkapkan bahwa pentingnya keluarga dan lembaga- lembaga pendidikan untuk menjalankan peran dan tanggung jawabnya dalam memberikan stimulan serta arahan yang tepat agar tercipta muslim yang unggul dan tangguh. Dengan bimbingan, arahan dari para orang dewasa, anak dapat berproses dalam hal mengenal siapa Allah, sifat- sifat Allah, bagaimana kewajiban manusia terhadap Allah, dsb. Mendidik anak dengan tiga perkara, sebagaimana hadits Nabi "Mendidik melalui tiga hal, meliputi: mencintai Nabi, cinta keluarga, dan membaca Al-Qur'an. Diharapkan anak sejak dini hingga dewasa kelak selalu dilindungi; Allah bersama dengan Nabi dan orang suci lainnya".

Program dan kegiatan membentuk perilaku juga kegiatan yang disarankan perlu dilakukan terus dalam kehidupan anak. Hal ini dilakukan agar anak memiliki kebiasaan yang baik. Perilaku yang dibentuk dengan cara pembiasaan belajar hidup bermasyarakat dan berdisiplin. Hal ini bertujuan guna menyiapkan anak agar dapat memiliki sikap dan perilaku dengan didasari nilai- nilai moral dan agama. Ayah dan ibu berperan dan bertanggung jawab penuh pada pendidikan anak dalam keluarga. Aspek spiritualitas merupakan aspek yang pertama, utama, dan terpenting sebagai landasan nilai hidup anak kelak di kemudian hari. Screbryakova,T.A; Makerycheva,Y.N; Kazakova, O.M (2018) menjelaskan bahwa dasar/ pondasi spiritualitas inilah yang akan merupakan salah satu kekuatan yang meneguhkan dan akan melindungi anak- anak

Lilis Madyawati, Marhumah, Ahmad Rafiq Urgensi Nilai Agama Moral Anak pada Era Society 5.0 
dari pengaruh negatif masyarakat era 5.0 dalam kehidupan.

Masa masyarakat keterbaharukan merupakan masa super teknologi, era kecanggihan, dan era kemudahan. Adanya kecerdasan buatan, bioteknologi, nanoteknologi, dan robot. Masyarakat di era ini diindikasikan dengan karakter yang kurang fokus dibanding dengan era milenial, namun lebih praktis. Era yang bercirikan masyarakat yang lebih mementingkan diri, lebih mendunia, lebih laku di pangsa pasar kerja, berpikiran terbuka, juga lebih ramah teknologi. Tidak seperti halnya media konvensional kertas. Layar kaca sudah merupakan media baru guna suatu pembaharuan dan penyebaran konten yang sangat visualis, kinestetikal, interaktif, terhubung dan portable (Aquilani, B.et.all, 2020). Perkembangan teknologi yang super cepat dan canggih ini harus dapat dipahami oleh para orang tua dalam hal memberikan dan mendampingi anak melalui pendidikan. Banyak hasil penelitian mengatakan bahwa sistem pendidikan yang telah dan sedang berlangsung ternyata belum sepenuhnya dapat sejalan dan mengantisipasi perubahan yang terjadi. Dengan adanya internet, dengan koneksi membuat dunia seolah semakin bertambah dekat dan menciut.

Menurut Al-Ghazali (dalam Scahaffhauser, D; 2021) tugas pokok orang tua yaitu membersihkan serta menyempurnakan diri manusia untuk bertaqarrub kepada pencipta-Nya. Melalui pendidikan, seorang manusia mendekatkan diri kepada Allah swt. Pendapat Abdul Rahman al-Nahlawi terdapat 2 fungsi pokok orang tua yaitu pengembang dan pemeliharan fitrah manusia, serta menginternalisasikan nilai- nilai positif dan religius dalam keluarga dan kehidupan. Orang tua tidak sekedar bertanggung jawab mendidik dalam arti mengajari anak- anak untuk beribadah kepada Allah swt. dalam rangka menegakkan kebenaran. Orang tua juga mempertanggungjawabkan tugas yang dilaksanakannya di hadapan Allah swt. Sawitri, D.E; Imran; Ramadhan, I (2021).

Orang tua dalam kaitannya dengan pendidikan di era masyarakat keterbaharukan era 5.0 hendaknya memiliki kemampuan dalam hal mengenalkan dan melatih sejak dini seorang anak untuk dapat berpikir tingkat tinggi. Ada berbagai usaha yang dapat dilakukan orang tua yaitu: a) mengajari untuk mengingat apa yang telah dilakukannya. Anak diajak berdiskusi tentang apa yang telah dilakukan pagi- petang; b) mengajak memahami sesuatu dengan benar. Jika anak melakukan sesuatu yang negatif yang tidak berkenan di hati orang tua, sampaikan alasan yang dapat diterima anak, agar anak tidak mengulanginya lagi; c) membimbing anak mengaplikasikan ilmu yang didapat; d) mengajak anak belajar menganalisis. Misalnya, usai belajar dan merapikan mainan, mengajarkan kepada anak akibat dari mainan yang rapi; e) mengajari anak untuk melakukan evaluasi. Evaluasi bermanfaat memberikan pengetahuan atau konsep benar atau salah. Mengajak anak guna melihat manfaat mainan yang rapi; serta f) mengajak anak belajar suatu pikiran baru. Mengajarkan kepada anak mengembangkan pikiran dengan bimbingan orang tua. Gussevi, S; Muhfi, N.A. (2021).

\section{METODE PENELITIAN}

Penelitian ini merupakan penelitian kualitatif yang analisis datanya tidak menggunakan statistik, melainkan berupa pernyataan- pernyatan bentuk verbal. Desain penelitian berupa library rsearch atau studi pustaka. Zed (2004) menyatakan bahwa penelitian atau studi pustaka yaitu serangkaian kegiatan pengumpulan data berupa

Lilis Madyawati, Marhumah, Ahmad Rafiq Urgensi Nilai Agama Moral Anak pada Era Society 5.0 
pengumpulan pustaka, membacanya, mencatat dan mengolah menjadi bahan penelitian. Dengan demikian, peneliti menggunakan sumber pustaka guna mendapatkan serta mengumpulkan data-data penelitian. Peneliti membatasi hanya pada koleksi-koleksi pustaka saja, tidak memerlukan riset atau terjun ke lapangan. Adapun obyek penelitian mencakup obyek formal dan obyek material. Obyek formal berupa data-data terkait dengan nilai agama dan moral dan masyarakat/society 5.0. Obyek materialnya berupa sumber data yaitu orang tua. Metode pengumpulan data yang dipergunakan metode simak, dengan menyimak bahasa (Mahsun, 2011). Peneliti memilih dan memilah data dengan cara melakukan penyimakan. Setelah melakukan penyimakan, langkah berikutnya mencatat bentuk yang sesuai dengan pemakaian bahasa secara tertulis. Adapun teknik untuk menjamin keabsahan data yang dihimpun, peneliti menggunakan trianggulasi (crosscheck) data antara data yang dihimpun melalui studi pustaka dengan data-data hasil observasi juga dengan teknik dokumentasi.

Peneliti mengambil data berupa nilai moral dan agama yang ditanamkan melalui peran orang tua pada society 5.0. Data-data yang telah ditemukan selanjutnya dilakukan pencatatan pada lembar kartu data. Kartu data ini diperlukan peneliti dalam langkah dan pengumpulan data serta analisis data untuk mempermudah dalam pengelompokkan dan penganalisisan data. Hal- hal yang dibutuhkan dalam kartu kata berupa segala sesuatu dalam kaitannya dengan nilai moral dan agama serta society 5.0. Data- data dianalisis menggunakan metode pilah dengan unsur penentunya nilai moral dan agama. Sebelum dilakukan analisis data, pneliti melakukan professional judgment kepada ahli terkait konten/ materi penelitian.Selanjutnya peneliti melakukan analisis terhadap moral dan agama anak yang ditanamkan orang tua dalam menghadapi masyarakat era 5.0. Pada prinsipnya analisis data yang dilakukan peneliti dengan cara menjabarkan data ke dalam bagian dan karakteristiknya. Hal ini dilakukan usai data diteliti secara cermat. Dengan cara ini peneliti dapat memperoleh hal- hal penting yang sesuai dengan kajian penelitian yaitu society 5.0 dan nilai moral agama. Kategori dan karakteristik ini selanjutnya oleh peneliti digunakan untuk melakukan pembatasan data. Peneliti melakukan content analysis (Bungin, 2012), dilakukan untuk membuat inferensi-inferensi yang replicable berdasarkan konteksnya, bertujuan untuk mendapatkan pemahaman yang lebih tajam tentang permasalahan yang diteliti. Oleh karena itu, peneliti meneliti dan menganalisis teks literatur tentang nilai agama moral anak dan society 5.0.

\section{HASIL DAN PEMBAHASAN}

\section{A. Moral dan Agama Anak pada Era Masyarakat Keterbaharukan dalam perspektif Hadits}

Berdasarkan hasil telaah teori sehubungan dengan pentingnya nilai moral dan agama anak pada era masyarakat keterbaharukan yang diindikasikan dengan semakin mengglobalnya kemajuan teknologi informasi komunikasi, peneliti dapat merumuskan hal-hal yang dapat dijadikan alternatif pilihan dalam era society 5.0 sebagai berikut:

1) Pola asuh orang tua berkaitan erat dengan pendidikan moral dan agama pada anak. Orang tua hendaknya memberikan pola asuh yang tepat untuk perkembangan moral dan agama anak. Berdasar observasi hasil perkembangan moral agama, anak memahami perlaku mulia dan membedakan perilaku baik dan buruk. Hal yang perlu

Lilis Madyawati, Marhumah, Ahmad Rafiq Urgensi Nilai Agama Moral Anak pada Era Society 5.0 
dilakukan orang tua yaitu: memperkenalkan nilai moral dan agama yang berlaku di masyarakat, serta melibatkan anak dalam hal masalah moral dan agama, menananamkan perasaan penuh kasih dan kehangatan, bertanggungjawab akan kesalahan, mengajarkan kedisiplinan, memperkuat kata hati. Selain itu orang tua juga perlu memperkuat tingkah laku altruistic dan menjadikan dirinya sebagai model/panutan dalam hal menjalankan moral dan agama.

2) Lingkungan masyarakat merupakan suatu komunitas untuk tempat tinggal individu. Lingkungan menyebabkan terciptanyan pola interaksi antar individu. Pergaulan dalam lingkungan inilah yang dapat mempengaruhi dan mengubah perilaku, sifat, adat istiadat, akal pikiran, pengetahuan serta etika perilaku individu. Hal ini dapat dimaknai lingkungan pergaulan dapat menghasilkan kemajuan atau kerusakan/ kemunduran. Di sinilah dibutuhkan peran orang tua.

3) Teman sebaya (peers) cenderung dengan tingkat usia yang sama. Dari kelompok teman sebaya ini anak memperoleh umpan balik. Anak dalam persetemanan sebaya itu juga mempunyai minat, tingkah laku yang baik maupun saling adu keberanian hingga mengakibatkan keonaran. Banyak hal yang mempengaruhi perilaku teman sebaya seperti: mereka saling mengimitasi, memberi pengaruh psikhis, hingga simpati yang hebat. Kelompok persetemanan sebaya ini ada kelompok yang positif maupun kelompok yang negatif/ buruk.

4) Keluarga dengan kondisi sosial ekonomi yang lebih dari cukup/ tinggi relatif lebih dapat melakukan pendampingan maupun memberikan nasehat- nasehat kepada anaknya. Orang tua tidak disibukkan melakukan pemenuhan kebutuhan rumah tangga. Berbeda dengan orang tua dengan kondisi social ekonomi yang rendah. Orang tua sangat mungkin pergi dini hari hingga petang untuk memenuhi nafkah keluarga. Kepemilikan pemahaman dan implementasi nilai moral agama anak kurang dapat terpantau.

Berdasarkan hasil penelitian tersebut, maka:

1) Perlu dihimbau orang tua yang dapat mendidik anaknya seperti Rasulullah saw. Sangat sulit mewujudkan karakter yang bertipe seperti Rasulullah. Sekalipun demikian dalam kondisi apapun sebagai umat Islam diusahakan agar mengikuti jejak Rasul sebagai orang tua panutan dalam Islam. Orang yang berkepribadian seperti Rasulullah saw. hendaknya dapat: a) meneladani sifat Rasul, dengan selalu berkata benar, cerdas, dan amanah; b) menjalankan amanah sebagai orang tua semata- mata karena Allah, orang tua yang ikhlas, bertanggung jawab tanpa pamrih; c) berkewajiban melaksanakan perintah Allah melindungi keluarga dari kehidupan akhirat yang baik; d) jauh dari dosa besar dan mencintai penuh kasih terhadap anakanaknya. Pesan Nabi dalam mendidik anak, At-Tirmidzi meriwayatkan, Rasul saw. menyatakan: "Pemberian ayah yang paling baik kepada anaknya yaitu memberi teladan yang baik".

2) Orang tua yang memiliki tanggung jawab pendidikan intelektual bagi anak- anaknya. Memberikan pendidikan, kebiasaan berpikir yang bermanfaat, hukum, ilmu pengetahuan, kesadaran berbudaya, dan peradaban ilmiah. Perlunya orang tua mengikatkan anak dalam Islam, memahami dan melaksanakan tuntunan Al-Qur'an, mengenal sejarah dan 
kebudayaan Islam dan gerakan- gerakan dakwah Islam. Orang tua yang bertanggung jawab dalam hal menjauhkan anak- anak dari gejala dan kerusakankerusakan besar yang tersebar di masyarakat. Kerusakan besar, seperti: pornografi, radikalisme, kriminalitas, dan sejenisnya berdampak besar terhadap akal, ingatan, serta fisik manusia.

3) Membangun Generasi Robbani

Untuk menjadi Generasi Robbani orang tua dapat meneladankan dan mengenalkan kepada anak tentang lima sifat. Pertama, Shohibul Aqidah, dimaknai keimanan yang kokoh yang menetap hanya kepada Allah. Hal ini ditunjukkan melalui menjalankan kewajiban, bertauhid, patuh pada Allah, beriman kepada Rasul, malaikat, dan kitabNya, hari akhir, takdir baik dan buruk, mengimani ketetapan sesuai Al-Qur'an dan As-Sunnah. Kedua, Al-Istiqomatu bil ibadah, beribadah yang istikomah. Hal ini diaplikasikan melalui kehidupan dengan memberikan dan mengajarkan keteladanan kepada anak terkait: tidak meninggalkan salat, salat di awal waktu secara berjamaah dan menambah salat- salat sunnah. Ketiga, yaitu husnul khulu, senantiasa menjaga ahlak yang baik. Orang tua memberikan contoh dalam hal berbuat santun, berbahasa yang sopan dan baik. Keempat, Atta'awun. Artinya, mengajarkan kepada anak untuk kooperatif, bisa bekerja sama, bergotong royong, bantu membantu dan tolong menolong. Tolong menolong dan bantu membantu yang dimaksud yaitu membantu dalam hal kebaikan yang saling memberi manfaat, bukan membantu atau menolong dalam kemaksiatan. Kelima, yaitu mandiri mengajari anak untuk terus menerus misalnya dalam memecahkan masalah maupun menyelesaikan suatu kegiatan/ aktivitas. Berusaha terus tahap demi tahap, berdaya juang besar, pantang menyerah. Menyelesaikan masalah dengan cara yang benar, jujur, sesuai tuntutan Islam.

Membangun Generasi Robbani ini tidak dapat dilakukan sendirian. Generasi Robbani dibangun dengan mengkolaborasikan dan mensinergikan banyak pihak. Keluarga, sekolah, dan masyarakat perlu bersama- sama mewujudkan dan mengupayakannya. Peran orang tua sangat dibutuhkan untuk membentuk watak anak yang bertabiat baik, berahlak mulia, cara pandang dan bersikap, cara berpikir yang didukung dengan sifat dan sikap terpuji. Sifat jujur, terbuka, sportif, dan menghormati orang lain juga merupakan komponen penting pembentuk Generasi Robbani.

4) Kebiasaan/habits yang dibangun orang tua dalam kehidupan sehari- hari. Kebiasaan yang dilakukan orang tua dalam keseharian memiliki pengaruh besar dalam kehidupan anak. Terdapat sejumlah hal yang penting diperhatikan orang tua: a) Orang tua bertanggung jawab kepada anak bersifat duniawi, ukhrowi, dan teologis. Pengaruh yang diberikan orang tua bersifat empiris, genesitas, dan hereditas; b) Durasi waktu anak tinggal di rumah bersama orang tua lebih banyak daripada anak tinggal di luar rumah; c) Pengaruh dalam segala hal yang diberikan orang tua kepada anak memiliki kekuatan tinggi daripada pengaruh dari orang lain; d) Peran seorang ibu sangatlah besar dalam rangka menciptakan rumah bagaikan 'surga' bagi anak- anaknya.

B. Peran orang Tua dalam Pendidikan Moral dan Agama Perspektif Hadits

Nilai moral dan agama perlu diberikan kepada anak sejak awal kehidupan. Hal ini

Lilis Madyawati, Marhumah, Ahmad Rafiq Urgensi Nilai Agama Moral Anak pada Era Society 5.0 
sangat penting guna mengkonstruksi perkembangan psikhis anak. Cara yang paling mudah dilakukan yaitu melalui peran orang tua dan keluarga. Sebagaimana penelitian yang dilakukan oleh Smetama (2010) mengungkapkan bahwa penanaman agama dan moral pada anak dibangun berdasar interaksi sosial dari anak dan orang tua. Interaksi sosial yang terjalin antara hubungan orang tua dan anak juga sangat ditentukan oleh afektif/sikap dan kognitif orang tua. Orang tua juga bersikap baik dapat mempengaruhi anak, karenanya anak dapat termotivasi dalam mendengarkan serta merespon pesan- pesan yang disampaikan orang tua terkait dengan ajaran moral dan agama. Orang tua dengan kepemilikan aspek afektif dan kognitif yang baik juga menguntungkan dan efektif bagi anak. Utamanya hal ini dapat terjadi saat anak melakukan pelanggaran/ penyimpangan terhadap moral. Pesan atau teguran yang disampaikan orang tua akan diingat oleh anak. Berbeda dengan penelitiannya Gogo (2020) yang mengungkap bahwa pendidikan karakter dan moral anak merupakan komponen penting dalam keberlangsungan sebuah peradaban. Nilai- nilai moral seperti kejujuran, saling menghormati, kesopanan, serta tanggung jawab sosial sangat membantu individu dalam kehidupan yang membaik.

Keterlibatan orang tua maupun keluarga dalam menanamkan nilai agama dan moral anak sangatlah penting. Tidak hanya menanamkan agama kepada anak sejak dini. Hal ini juga dapat mencegah dan terjadinya paham radikalisme dan ekstremisme. Di satu sisi, di zaman society 5.0 penanaman peran agama dan keluarga tampaknya yang dilakukan orang tua belum optimal. Hal ini dimungkinkan lemahnya kontrol serta kurangnya keteladanan yang dibangun belum diberikan di masa awal kehidupan anak.

Fenomena yang menggejala di masyarakat akhir-akhir ini justru manusia bermunculan keluarga yang rentan terhadap paham ekstremisme atau bahkan menjadi penyebar ekstremisme. Idealnya para orang tua aktif dan peduli dalam menstimulan pendidikan agama dan moral. Pendidikan moral dan agama pada anak di era society 5.0 sebagai wahana dalam mewujudkan kepribadian anak dan bangsa yang lebih baik dan religius. Peran dan keteladanan orang tua utamanya ibu dalam society 5.0 ini termasuk mencegah anak dari pornografi, NAPZA, bebasnya pergaulan, serta bahayanya gadget. Dalam kaitannya dengan teknologi canggih, ada baiknya orang tua juga harus menambah pengetahuan mengenai penggunaan teknologi, mengarahkan dalam pemanfaatan perangkat serta media digital secara tegas, melakukan pembatasan dan pengaturan waktu dalam memanfaatkan perangkat digital dengan interaksi dunia nyata. Dapat pula orang tua memilihkan program/aplikasi positif yang dapat memberikan dampak baik pada perkembangan anak.

Intensitas pendampingan terhadap anak perlu lebih ditingkatkan dengan cara melakukan pendampingan saat anak menggunakan perangkat digital. Selain itu juga perlu melakukan pembatasan usia anak untuk dapat memanfaatkan media digital. Terdapat sejumlah strategi yang dapat dipergunakan dalam pendidikan moral dan agama bagi anak. Pertama, menanamkan rasa cinta pada Allah swt. Rasa cinta kepada Allah ini dapat dilakukan melalui pembelajaran saintifik. Kepada anak diperkenalkan dan dipahamkan tentang mahluk- mahluk ciptaan Tuhan, yang dilakukan melalui proses mengamati. Sebagaimana penelitian yang

Lilis Madyawati, Marhumah, Ahmad Rafiq Urgensi Nilai Agama Moral Anak pada Era Society 5.0 
dilakukan oleh Scott, E.C; Matzke, N.J (2007)

bahwa melakukan pengamatan dan pemahaman terkait evolusi pada ilmu biologi, memahami mahluk- mahluk ciptaan Tuhan belum cukup hanya dilakukan dengan luasnya pendidikan, juga tidak sekedar cukup melakukan pengamatan pada adanya hubungan sebab akibat. Untuk ini diperlukan strategi dan kekuatan supranatural (seperti kedalaman agama).

Pemberian pendidikan moral dan agama bagi anak dapat melalui menciptakan rasa aman pada anak. Pendidikan ini hendaknya memperhatikan saat anak dalam rasa aman, tak ada unsur paksaan ataupun kekerasan. Rasa aman akan memberikan dampak positif saat anak menerima pesan dan materi- materi terkait moral dan agama. Keluarga menjadi tempat bagi anak untuk dapat mengenal, menumbuhkan, menanamkan, serta mengembangkan moral dan agama. Pendidikan ini dapat ditemukan pada kehidupan anak sehari- hari meliputi: kejujuran, kedisiplinan, peduli dan perhatian kepada orang lain, menghormati, keadilan, kemandirian, tanggung jawab, dan berdaya juang. Pada anak berusia 3- 6 tahun, pengenalan nilai agama dan moral anak berada pada tahapan the fairy tale stage. Pada tahapan ini anak mengenal Tuhan melalui fantasi dan emosinya. Pendidikan moral agama disarankan banyak dilakukan melalui dongeng. Penerimaan moral agama sangat tergantung pada faktor luar dari diri anak. Anak cenderung mengikuti yang dilakukan dan dikerjakan orang dewasa.

Hal yang dianjurkan dipersiapkan oleh keluarga dan orang tua dalam kaitannya dengan kesiapan pendidikan moral agama, yaitu: pengasuhan, ada tidaknya/besar kecilnya masalah dalam keluarga, kualitas hubungan keluarga, serta interaksi yang terjadi dalam keluarga. Sayangnya, Santiago (2014) melakukan telaah dan hasilnya menginformasikan bahwa belum terdapat studi/ kajian formal tentang adanya pengaruh keluarga, sekolah, gereja/ tempat ibadah, hubungan persetemanan dengan teman sebaya serta budaya terhadap kesetiaan beragama pada anak- anak muda di Puerto Rico. Oleh karena itu tidak dijumpai datadata valid tentang tingkat religiusitas anakanak muda/ remaja yang dapat dipergunakan sebagai standar penilaian tingkat keberagaman pada anak muda.

\section{SIMPULAN}

Pentingnya menanamkan pendidikan agama dan moral pada anak, perlu dipersiapkan sumber daya manusia yang siap menghadapi tantangan, menghadapi gejolak teknologi, dan ketidakpastian di era society 5.0. Lembaga pendidikan anak usia dini bersama orang tua peka terhadap masalah ini. Turut berperan serta aktif menyikapi dan menyiapkan anak yang kelak menjadi muslim yang unggul. Adanya suatu generasi yang siap bersaing dan berkiprah tanpa batas. Anak disiapkan untuk memiliki berbagai kemampuan utama guna menghadapi berbagai tantangan. Selain itu tak kalah pentingnya halhal seperti; kesesuaian pola asuh orang tua, pengaruh lingkungan, persetemanan sebaya, serta kondisi sosial ekonomi orang tua yang turut berkontribusi terhadap pemahaman dan implementasi pendidikan nilai moral an agama pada anak di era society 5.0.

\section{DAFTAR PUSTAKA}

Ahmad, A; Amalia, D. (2018). The Relationship Between Attachment and Self Character Values in Children with Working Mothers. International 
Conferences on Early Childhood

Education. Desember 2018.

Ananda, R. 2017. Implementasi Nilai- nilai Agama dan Moral pada Anak Usia Dini. Jurnal Obsesi Jurnal Pendidikan Anak Usia Dini. Vol 1 (1). p. 19- 31.

Aquilani, B, et.all (2020). The Role of Open Innovation and Value Co-Creation in the Challenging Transition from Industry 4.0 to Society 5.0: Toward a Theoretical Framework. Sustainability. 12, 1- 21.

Bennett, S; Braak, J; Heller, S. Computer \& Education. https://www.journals. elsevier.com/computers- and- education. Bungin, B. (2012). Analisa Data Penelitian Kualitatif. Jakarta: Rajawali Pers.

Gogo, J.O. (2020). The Contribution of Education to Moral Decay in Kenya Challenges and Prospects. International Journal of Education Humanities and Social Science, 3(1), 20- 32.

Gussevi, S; Muhfi, N.A. 2021. Tantangan Mendidik GenerasiMilenial Muslim di Era Revolusi Industri 5.0. Paedagogie. Vol. 2 (1). p. 46- 47

Mahsun. (2011). Metode Penelitian Bahasa, Tahapan, Strategi, Metode, dan Tekniknya. Jakarta: Rajawali Pers.

Hanafiah, Soomro, M. 2021. The Situation of Technology Companies in Industry 4.0 and The Open Innovation. Journal of Open Innovation: Technology, Market, and Complexity. Vol.7 (1). P 2-20.

Outlook for Economic Activity and Prices. (2016).

Prasetyo, H; \& Sutopo, W. (2018). Industri 4.0: Telaah, Klasifikasi Aspek dan Perkembangan Riset. Jurnal Teknik Industri, 13 (1).

Qasem, M.H; AlMobaideen. (2019). Heterogeneity in IoT-Based Smart City Designs. International Journal of
Interactive Mobile Technologies. 13 (12), 210- 225.

Rahim, A. (2018). Pendidikan Islam dalam Surah Luqman. Jurnal Ilmiah Al Qalam. 12 (1), 51- 74.

Santiago, E.P.A. (2014). The Relationship of Family, Church, School, Peers, Media and Adventist Culture to the Religiosity of Adventist Youth in Puerto Ciro. Dissertation. Andrews University.

Sarif, S.M. (2017). Society 5.0. Qalb with Tawhidic Paradigm. Journal of Education and Social Sciences, 8(1).

Sawitri, D.E; Imran; Ramadhan, I. 2021. Sosialisasi Keluarga dalam Membentuk Kepribadian Anak. Jurnal Sosialisasi. Vol. 6(2) p. 10- 21.

Schaffhauser, D. (2021). Forever Changed: Education Predictions for 2021. The Journal Transforming Education Through Technology.

Scott, E.C; Matzke, M.J. (2007). Biological Design in Science Classrooms. Proceeding PNAS, 104 (1), 8669- 8676.

Screbryakova, T.A: Makarycheva, Y.N; Kiazokova, O.M. 2018. European Journal of Natural History. Vol.1. p. 5961.

Smetana, J.G. (2010). The Role of Parents in Moral Development: A Social Domain Analisis. Journal of Moral Education, 28 (3), 311- 321.

Tariq, M.M; Tania, L; Gutreen, Z. 2021. Renewable energy Consumption and Health Outcomes: Evidence from Global and Data Analysis. Pakistan Journal Commence and Social Sciences. Vol. 15 (1) p. 58- 93.

Zed, Mestika. (2004). Metode Penelitian Kepustakaan. Jakarta: Yayasan Obor Indonesia. 
Al-Hikmah: Jurnal Agama Dan Ilmu Pengetahuan

P-ISSN 1412-5382

Vol. 18 No.2, Oktober 2021

E-ISSN 2598-2168

Lilis Madyawati, Marhumah, Ahmad Rafiq Urgensi Nilai Agama Moral Anak pada Era Society 5.0 